\title{
Külpe on Cognitive Attitudes
}

\author{
Arnaud Dewalque
}

\begin{abstract}
This paper offers a reconstruction of Külpe's theory of cognitive attitudes from the perspective of contemporary debates about cognitive phenomenology. I argue that Külpe's view constrasts with analytic mainstream approaches to the same phenomena in at least two respects. First, Külpe claims, cognitive experiences are best described in terms of occurrent cognitive acts or attitudes toward sensory, imagistic or intellectual contents. Second, occurrent cognitive attitudes are intransitively conscious in the sense that they are experienced by, or phenomenally manifest to, the subject. I call the combination of those two claims the conscious cognitive attitudes theory. I suggest that, despite some difficulties, this theory offers a worth-considering alternative to contentual and/or nonphenomenological theories of cognitive phenomena.
\end{abstract}

Keywords: Act Psychology, Consciousness, Cognition, Phenomenology, Külpe.

\section{Introduction}

Over the last two decades or so, investigations dedicated to cognitive experiences have been spectacularly revived in philosophy of mind. Very roughly, the key idea is that understanding a sentence (Strawson 1994/2010, pp. 5-11) or having an occurrent thought (Siewert 1998, pp. 276277) are phenomenally conscious experiences in some relevant and interesting sense. According to a widespread formulation, there is 'something it is like' for the subject to understand a sentence or to have a conscious thought. There is something it is like for you, say, when you eventually get the meaning of what a foreign language speaker just told you or when it suddenly occurs to you that you are late to a crucial appointment.

Such considerations are thought-provoking, for they contradict the view that the only mental states that qualify as phenomenally conscious experiences are perceptual and emotional states-a view which somehow became orthodoxy in mainstream analytic philosophy. Supporters of cognitive phenomenology want to challenge this orthodoxy by maintaning (i) that there is more to cognitive episodes than just information processing describable from an external, third-person perspective, and (ii) that accounting for this 'plus' involves a story about the experiential, or phenomenal, character of cognition itself. ${ }^{1}$

\footnotetext{
1 Throughout this paper, I will use 'experiential' and 'phenomenal' as equivalent, and I will make no distinction between 'experience' and 'conscious experience.'
} 
Its apparent simplicity notwithstanding, the notion of cognitive experience certainly calls for considerable unpacking if it is to be understood, and discussed, in a satisfying way. One way of making an intuitive, preliminary case for cognitive experiences is to consider episodes of conscious thinking in which the subject comes to realise that something is the case. For the sake of convenience, call such episodes realising-experiences. ${ }^{2}$ Several cases of realising-experiences have been discussed in the literature. For example, you may realise that a word sequence you previously failed to understand actually is a meaningful sentence (see, e.g., Horgan \& Tienson 2002, p. 523; Pitt 2004, p. 27), that a mathematical equation whose correctness was not obvious to you actually is correct (Chudnoff 2015, p. 1), or that a sentence is equivocal and may be unterstood in at least two ways (Horgan \& Tienson 2002, p. 523; Siewert 2007, p. 16; Smithies 2013 , p. 750). Despite some undisputable differences, it is plausible to say that all those cases exhibit a common pattern, which justifies gathering them under the head of realising-experiences. Under realising-experiences, I understand experiences which seem to involve a switch from one situation S1 to another situation S2, which phenomenally contrasts with S1. Contemporary supporters of cognitive phenomenology argue that the best explanation for this phenomenal contrast is that S2 exhibits what may be called, for want of a better expression, a cognitive dimension that was utterly absent in S1. Since the switch from S1 to S2 may be said to be phenomenally manifest to youi.e., it "feels" a certain way for you to realise that $p$-, the cognitive dimension that is ex hypothesi responsible for this switch may be said to be phenomenally manifest, too.

However instructive, the phenomenal contrast strategy I just referred to clearly left a number of issues unresolved (for a recent overview, see Jorba \& Moran 2016; Montague 2017). Even if it succeeds in establishing that S2 phenomenally differs from S1, it does not prove that S2's phenomenal character cannot be explained by referring to sensations or feelings. Is S2's experiential character reducible to sensory and/or emotional phenomenology? Opponents to cognitive phenomenology typically answer yes. They claim that the experiencial character of cognitive episodes is exhaustively accountable for in terms of inner speech, mental imagery, or a combination thereof (see, e.g., Prinz 2011). Supporters of cognitive phenomenology, on the other hand, answer no. They take S2's phenomenal character to involve a distinctively cognitive, nonverbal and non-imagistic ingredient, a phenomenal 'plus' that is beyond and above sensory or emotional phenomenology.

Oswald Külpe and other representatives of the Würzburg School of thought-psychology are sometimes seen as the first champions of this last position. ${ }^{3}$ As a matter of fact, they acknowledged the existence of distinctively cognitive experiences and considered the latters to be not reducible to sensory and emotional experiences. This position, however, was not exceptional

\footnotetext{
2 In contemporary literature, it is more customary to talk of the phenomenal contrast strategy-or simply of “contrast arguments" (see, e.g., Montague 2016, p. 178). Talking of realising-experiences just is a more intuitive way of capturing the facts that are referred to by supporters of the contrast arguments.

${ }^{3}$ Külpe has gone down in history as one of the leading figures of the Würzburg School of thought-psychology, whose main representatives also include Narziss Ach, Karl Marbe, August Messer, Karl Bühler, and Otto Selz (see, e.g., Hammer 1994). The place and influence of Külpe within the Würzburg School, however, is a matter of controversy. Even if it is sometimes referred to as the "Külpe School" (see, e.g., Stumpf 1906, p. 25 fn.), it is probably more fair to see the Würzburg School as a "community of researchers" who carried out interconnected, though relatively autonomous investigations (Caramelli \& Borghi 1995, p. 352). For instance, Karl Marbe, who became head of the Würzburg psychological institute in 1909, probably never considered himself a student of Külpe (see, e.g., Gundlach 1999, p. 112). So did Otto Selz (see Herrmann 1999). Moreover, there is evidence that Karl Bühler's works, independently from Külpe's, played a significant role in the constitution of the Würzburg School (see Ogden 1951, p. 11).
} 
in early twentieth-century philosophy. Montague, among others, rightly points to the fact that "the existence of cognitive phenomenology was completely accepted by many Phenomenologists and early twentieth-century philosophers," and that "the denial of its existence seems to be a symptom of the dominance of behavioral/functionalist conceptions in contemporary philosophy of mind" (Montague 2016: 177).

This paper deals with Külpe's pioneering contribution to the debate about the nature and structure of cognitive experiences. Provided that there are experiences which may be deemed 'cognitive' (more on this in section 1), the issue I want to address is how to best describe them. Very roughly, it is probably not unfair to say that contemporary mainstream accounts tend to construe cognitive phenomena either in terms of phenomenal contents or in terms of propositional attitudes that lack any phenomenology. I argue that Külpe's view constrasts with both approaches. First, he claims, cognitive experiences are best described in terms of cognitive attitudes toward sensory, imagistic or intellectual contents. This claim breaks with a purely contentual approach to mental phenomena. Second, cognitive attitudes are intransitively conscious in the sense that they are experienced by, or phenomenally manifest to, the subject. This claim contrasts with the usual way contemporary analytic philosophers conceive of propositional attitudes. ${ }^{4}$ The combination of those two claims form the core of what I will call the conscious cognitive attitudes theory.

My plan is as follows. In section 1 I will review some instances of cognitive experiences that showed up in the works of Külpe and other Würzburgers. Sections 2 and 3 will be devoted to introduce Külpe's description of those cognitive experiences. After a brief critical discussion, I will come to the conclusion that, despite some difficulties, the theory of conscious cognitive attitudes offers a worth-considering alternative to contentual and/or nonphenomenological approaches to cognitive phenomena.

\section{The Facts}

It certainly is trivial to state that cognitive experiences-thinking, judging, reasoning, and the like-play a dramatic role in the mental life of human adults. If we are to turn this triviality into a philosophically relevant claim, some clarification work is required.

To begin, the notion of distinctively cognitive experience may be minimally characterised as follows: For every subjective experience $E, E$ qualifies as distinctively cognitive if it is not reducible to sensory (imagistic and/or verbal), algedonic (pain/pleasure), or emotional (affective and/or conative) experiences - or to a combination thereof. ${ }^{5}$ Admittedly, this left us with a merely negative characterisation. Does this minimal understanding suffice to get a preliminary grip on what cognitive experiences are? I believe it does, on the condition, however, that some relevant examples are provided. The business of the present section precisely is to review some putative instances of cognitive experiences that showed up in the works of Külpe or other Würzburgers.

\footnotetext{
${ }^{4}$ See, e.g., Montague 2016, p. 25: "The traditional view of propositional-attitude states [in analytic philosophy, AD] is that they do not possess phenomenology, even when occurrent rather than dispositional." This traditional view, however, has begun to be challenged. See, e.g., Klausen 2008, Kriegel 2015, Jorba 2016, Dorsch 2016.

${ }^{5}$ Interestingly, the early explorations of thought-processes carried out by Külpe and Ach do not disconnect cognition from conation, for the experiments designed to investigate thought-processes involved the presentation of a goal and the willingness to reach the goal (see, e.g., Ach 1905). Yet, I won't expand here on the teleological dimension of thought-processes (see, in this respect, Caramelli and Borghi 1995).
} 
My motivation for doing so is twofold. First of all, scientific psychology, Külpe writes, deals with the facts given in the experience. ${ }^{6}$ So, when Külpe and the others claimed that a change of theoretical framework was required, ${ }^{7}$ they did so- or at least pretended to do sounder the pressure of empirical facts. As Külpe wrote to his former student, Robert Ogden: “The important thing is to understand the facts better, and with them alone we shall have much to do for a long time" (Ogden 1951, p. 16). Next, reviewing the subjective experiences at issue may serve a critical role in the overall strategy of shifting back from relatively controversial interpretations to less controversial facts. The pioneering works of the Würzburgers notably gave rise to a huge debate with Titchener (see Titchener 1909) regarding what exactly introspection and introspective reports reveal about cognitive experiences. Now it has been suggested that the Külpe-Titchener controversy might prove less substantial than usually believed. The disagreement, it seems, is not about the existence of some observable facts, but only about the description or interpretation of those facts. ${ }^{8}$ If this suggestion is correct, then returning to the empirical facts or phenomena at issue might provide us with a less controversial starting point.

What, then, are the facts that prompted Külpe to introduce distinctively cognitive 'elements' in his psychology?

$1 /$ One first, very specific set of facts is offered by the practice of philosophy itself. Ogden reports the following conversation with Külpe:

Regarding the character of thought as a distinct mental element, [Külpe] tells me that the idea first came to him in the summer of 1898 while lecturing on Leibniz, when it occurred to him that the 'monads' were not concepts but thoughts (Ogden 1911, p. 185).?

Getting the meaning of philosophical concepts, and accepting or rejecting philosophical claims, arguably are instances of cognitive experiences in the relevant sense. A very similar point has been made, recently, by Uriah Kriegel. Consider, for example, Spinoza's claim that "the order and connection of ideas is the same as the order and connection of things." The first time you read this sentence, Kriegel writes, you just may feel uncertain about what it means and whether it should be accepted or not. Then, after closer examination, you may undergo a realisingexperience to the effect that you now associate a certain thought to Spinoza's sentence and eventually decide to accept or reject it (see Kriegel 2015, pp. 101-105).

That said, understanding a philosophical thought is a relatively sophisticated and unusual instance of cognitive experience. The triviality I mentioned at the beginning of this section, however, was about the prominent place of cognitive experiences in ordinary, non-philosophical human life. As a matter of fact, Külpe's opinion is that cognitive episodes, far from being

${ }^{6}$ Cf. Külpe $1893 / 1895$, p. 1: "The business of all science is the description of facts". See Ogden 1951, p. 8, who adds: "The notable omission of many significant topics [in Külpe 1893, AD] appears to be attributable to a paucity of facts for which [Külpe] was unwilling to substitute surmises and hypotheses." Insistance on facts is also visible in Bühler 1907, 1908; Külpe 1922, pp. 128 sq.; etc.

7 Caramelli and Borghi (1995, p. 349) go so far as to speak of a "mutation of scientific paradigm."

8 As Hurlburt puts it, "Titchener and the Würzburgers were so focused on their differing views of the fundamental building blocks of thinking that they failed to appreciate how similar were their observations and descriptions of phenomena" (Hurlburt and Schwitzgebel 2007, p. 278).

${ }^{9}$ See also Külpe 1922, p. 319: "I have been led to an examination of thought-processes by quite specific issues. Indeed, it occurred to me that one can immediately think of objects of the external world, like physical bodies, or of metaphysical objects, like Plato's Ideas or Leibniz's monads, without having to form some presentations thereof.” 
restricted to intellectual or scientific occupations, rather are pervasive in one's everyday life. One striking way of putting this idea is to say that human life would not be what it is if cognitive experiences would not be part of it. This, again, bears a certain resemblance to the view held by contemporary proponents of cognitive phenomenology. As Montague puts it, it seems undeniable that "the experience of having thoughts is an essential part of what makes human life important, interesting, sad, happy, exciting, and so on" (Montague 2017, p. 297). More pointedly, Külpe insists that thought processes not only are part of our intellectual life, they also determine our everyday actions in many ways. For instance, it makes sense to say that "among the persons I come across, I greet only those that I know, not those I don't, and I answer a question only if I have understood it" (Külpe 1907, p. 606).

If we broaden the scope, then, it is plain that understanding a philosophical thought may be regarded as a particular instance of understanding a piece of discourse. Let's consider the question-and-answer example. To be sure, the understanding of a question does not occur in isolation. It is concomitant to seeing words written on the page, or hearing them, or recreating them by means of our imagination. And yet, understanding seems to be something else than just reading or hearing a sentence. Indeed, it may be insisted that there is a certain contrast between hearing-cum-understanding and hearing-without-understanding. In his paper on attention, Külpe mentions the following case:

\footnotetext{
My secretary is reading aloud to me. As I listen, I begin to think of something that I mean to do in the near future. When I have worked out my plan of action, I come back to the reading, and am made aware that I have lost some part of it [...]. While I was occupied with my plan, the tones of the reader's voice, which I seem to have followed without interruption, were empty, meaningless sounds (Külpe 1902, p. 41).
}

To put it differently, when I am made aware that I have lost track of a part of a speech, I undergo what may be called, once again, a realising-experience, an experience through which the contrast between hearing-cum-understanding and hearing-without-understanding becomes manifest to me. Plausibly, a satisfying theory of the mind should account for this fact.

2/ There is little doubt that, in addition to understanding-experiences, we undergo thinkingexperiences as well, experiences that do not show the same connectedness to perception and hence may be considered in turn a distinct set of cases. Recently, it has been suggested that this difference might be captured in distinguishing "unsymbolised thinking" from "cognitive phenomenology," or the phenomenology of "having thoughts" from that of "grasping thoughts." ${ }^{10}$ In our terminology, understanding-experiences, albeit irreducible to perceptual experiences, always occur in combination to them. They are, so to speak, accompanying experiences

\footnotetext{
10 See Hurlburt and Akhter 2008, p. 1370: "Pitt's cognitive phenomenology is a companion to, a feature of, or a conditioning of a verbal process, whereas unsymbolized thinking is its own separate phenomenon, not linked to or subjugated to or ancillary to some other phenomenon." See also, for a similar distinction, Voltoloni 2016. Voltoloni contrasts the fact of grasping thoughts — that is, understanding - with the fact of merely baving thoughts. Since grasping thoughts presupposes the sensory apprehension of a medium through which the toughts are conveyed (e.g., a spoken or written sentence), you cannot have an grasping-thoughs-experience without having at the same time a sensory experience. The existence of a grasping-thoughts-experience depends on the existence of a sensory experience, even though it is not reducible to the latter (simply put: there is more to understanding than just having sensations). By contrast, it seems one may experience occurring thoughts without having sensations. As Voltoloni (2016, p. 101) puts it: "The cognitive phenomenology of having thoughts is independent of any sensory phenomenology, while the cognitive phenomenology of grasping thoughts is merely irreducible to it."
} 
in the sense that they are not separable from perceptual (or imaginatory) experiences. Thinkingexperiences, by contrast, may occur independently and are separable from perceptual experiences. To draw from Külpe's previous example, when I think of something I mean to do in the near future, I have a conscious train of thought that is not properly speaking connected to my present perceptual situation, and even diverts me from it. In such a situation, I may just lose track of what someone is saying to me or, say, of the meaning of the text I am reading. It seems plausible to say that something similar occurs when we are asked to solve an abstract problem, as in Karl Bühler's experiments. Confronted with questions like "Do you understand the uttered sentence that $p$ ?" and asked to describe their subsequent experience, subjects usually report to have trains of thoughts and to be aware, not only of the thoughts, but also of the relation those thoughts have to one another and to the pursued goal (see Bühler 1908, p. 1 sq.). To be sure, thinking-experiences of that kind call for further analyses. Yet, for the reason I just mentioned, it seems sensible to treat them as a specific set of cases distinct from understanding.

3/ Before moving to Külpe's account of understanding and thinking, I would like to mention a third, much more controversial case, namely that of perceiving-and-recognising something or someone. Remember Külpe's example: "Among the persons I come across" when walking down the street, "I greet only those that I know, not those I don't" (Külpe 1907, p. 606). Whether perceptual experiences of this kind are constituted by a cognitive dimension is subject to lively debates in contemporary philosophy of mind (see, e.g., Siegel 2010; Siegel and Byrne 2016; Montague 2016, p. 136-141, 179). My goal is not to take stance in those debates, but merely to identify the undisputed fact that gave rise to diverging interpretations. In this case, one way of capturing the fact is to say that there is a contrast between perceiving-and-recognising, on the one hand, and having sheer sensations, on the other. Another member of the Würzburg School, August Messer, mentions the following scenario. Suppose you make a business trip abroad and spend the night in a small hotel in an unknown town. The place is not familiar to you. Now, in the middle of the night, you woke up suddenly hearing a roaring, growing sound, which at first you fail to identify. Then, after a very brief period of time, you remember the hotel is located in the vicinity of the railway station, and you take the roaring sound to be that of a train entering or leaving the nearby station. You now have an apprehension of the sound as that of a train. As Messer puts it, you're now enjoying an "objective interpretation" (objektive Deutung) of the sensation (Messer 1928, p. 45). Again, at first sight, this "objective interpretation" seems to be reducible neither to merely sensory ingredients nor to emotional feelings, for the same sensory ingredients and emotional feelings may occur with a different "objective interpretation" (if, for example, you misinterpret the roaring sound of the train for that of a distant thunderstorm).

Surely, the existence of this fact is uncontroversial. The disputed issue is how to account for it. Messer takes it that an act of "thinking" (Denken) is responsible for what he calls "objective interpretation," to the effect that perceiving-and-recognising episodes exhibit a kind of intertwining of sensations and thoughts. Here again, this view is not without anticipating more recent accounts, starting with that of Montague. Interestingly, Montague claims that perceiving-as involves what she calls "object-positing" (a notion not unlike Messer's "objective interpretation"), and that object-positing minimally amounts to think of what appears as falling under the concept of OBJECT. She concludes that "a full description of the content of many perceptual experiences reveals them to involve (quite literally) a thought' (Montague 2016, p. 137). The similarities are striking. However, one must be careful not to overestimate them. In the next section, I will suggest that Külpe's attitudinal analysis somewhat contrasts with contentual 
approaches of the same phenomena.

Let's take stock. The goal of this section was to review the main facts that prompted Külpe to introduce cognitive elements in his psychology. I have identified so far three types of facts:

1. understanding a piece of discourse;

2. thinking of something;

3. perceiving-and-recognising something or someone.

No need to say, the list is open and is far from exhausting the field of cognition. There arguably are other kinds of cognitive experiences that should be taken into consideration: judging that $p$, assuming that $p$, wondering whether $p$, and the like. Yet, for the purpose of this paper, I will confine myself to the above-mentioned examples.

It seems hardly disputable that, if the experiences I just touched upon may be called cognitive, there are cognitive experiences. After all, such experiences are quite ordinary and commonly acknowledged. Ogden makes a very similar point when he says that "the consciousness of meaning is a consciousness which we all experience; whether it can or cannot be analysed is another matter. But the problem is not materially helped, so far as I can see, by denying its psychological existence" (Ogden 1911, p. 195). So far, it seems we are on safe ground. Yet, that's where difficulties arise. What is the best way of describing the above-mentioned facts? The remainder of this paper is devoted to presenting Külpe's response to this question.

\section{Cognitive Attitudes}

In this section I introduce Külpe's first claim, namely, the claim that cognitive experiences are best described in terms of attitudes toward sensory, imaginatory or intellectual contents. In the next section I will briefly address the claim that cognitive attitudes are somehow experienced by the subject, even if they are not amenable to observation during their occurrence.

Let's have a closer look at the above-mentioned examples. At first sight, it is plausible to say that attention plays a role in at least some of them. In the secretary example, the fact that the sentences are heard without being understood (as "empty, meaningless words") clearly is due to a lack of attention or a situation of distractedness. Yet, it is not necessarilly so. Indeed, it is quite possible to construe a clear-cut case of hearing-without-understanding which has nothing to do with a lack of attention. This is exactly what you may experience when you try to understand a sentence in a foreign language. You focus your attention on what you hear, you are willing and trying to recognize some familiar word or verbal sequence, and, despite all your efforts, you fail to understand what the sounds mean. This additional example shows that understanding is not just a matter of attention. The same holds true for what Messer refers to as the "objective interpretation" of sensations. When I suddenly woke up in my hotel room due to an unidentified noise, my attention naturally is taken up by the noise: "I experience the sound in full attention," Messer writes (Messer 1928, p. 45). And yet, I may fail to recognise it for what it is, namely, the sound of a train entering the nearby station. Whereas attention certainly is part of the story, it is plain that referring to attention is not sufficient to account for the 'plus' that is responsible for the emergence of a cognitive experience.

Facing this issue, the Würzburgers felt themselves obliged to introduce new terms of art in order to capture the distinctive character of cognitive experiences. They talk about "states of consciousness" (Marbe 1901), “tasks" (Watt 1904), “determining tendencies” (Ach 1905, p. 187), 
"thoughts" and "thought connections" (Bühler 1907, p. 317; 1908).${ }^{11}$ Külpe himself gives an helpful overview of most of those terminological innovations in his review of Ach 1905, suggesting they all converge in the same direction. Indeed, it is Külpe's contention that, if we are to accommodate the existence of cognitive experiences a "brand new division of the mental facts" is needed (Külpe 1907, p. 603; my emphasis). Just adding some previously overlooked ingredients, like 'intellectual,' nonimagistic contents, will not do the trick. Rather, for our description to be faithful to the facts, Külpe claims, we need to revise our conception of the overall architecture of mental life.

In his 1904, Külpe already makes a first step towards a redefinition of the mental architecture by introducing the notion of "apprehension" (Auffassung). Interestingly, he was led to do so in analyzing perceptual states, hence states related to the third, most disputed set of examples. In Külpe's experiment about abstraction, a subject is visually presented with four meaningless different syllabes, each having a different colour and being made up of three letters of the same size. The subject simply is asked to report what she has just seen. But in some cases, before being presented with the visual scene, she is given a specific task to perform, like identifying the letters or identifying the colour of the syllabes. Unsurprisingly, the experiment shows that trying to perform a task like that creates a "preoccupation" or a "predisposition," which bears upon the subject's perceptual reports in various ways (e.g., the reports are more vague and uncertain when it comes to identify aspects that didn't match with the task to be performed). But, Külpe asks, how are we to account for the modifications induced by the tasks? When the subject is asked to identify the letters (say), is the colour of the syllabes "seen in a different way," or is it "apprehended in a different way" (Külpe 1904, p. 66)? Külpe maintains there is no reason to think that the sensory contents the subject experiences are different-why should they be? Rather, he claims there is a difference in the way the subject apprehends-or mentally handles - the sensory contents. For example, when the subject is asked to identify the letters, the subject has a less fine-grained apprehension of the colours of the syllabes: the colours "appear only as being the same or as being different" (id., p. 67). Külpe comes to the conclusion that it is necessary to make a distinction between one's having sensations and one's apprehending of the sensations. He maintains

\footnotetext{
that this distinction must be made in much the same sense in which we distinguish between physical phenomena and our consciousness of them; that, in other words, the old doctrine of an inner sense [...] must now have its opportune renewal in the domain of psychology (Külpe 1904, p. 67; quoted by Ogden 1911, p. 190).
}

Now, Külpe takes it that this does not only hold true for perceiving-and-recognising-experiences. The upshot, he believes, must be generalized to other kinds of experiences as well, including understanding- and thinking-experiences (more on this below). The key idea is that a purely contentual analysis of mental facts is not enough. Rather, cognitive experiences reveal the existence of mental acts, ways of apprehending or manipulating the mental contents. ${ }^{12}$

\footnotetext{
${ }^{11}$ For a reconstruction, see Caramelli and Borghi 1995; Rozestraten 2004.

12 This analysis bears strong ressemblance to that of Stumpf (see Stumpf 1906; Bühler 1908b). Külpe, however, adds that his "explanations have been written down before the publication of Stumpf's significant treatise on "Phenomena and mental Functions”' (Külpe 1907, p. 603 fn.). On Külpe and Stumpf, see Baumgartner and Baumgartner 1997; Kaiser-El-Safti 1997. Note that early phenomenologists like Carl Stumpf took the terme 'function' as synonymous to
} 
Ogden goes on suggesting that this diagnosis brings Külpe "in close contact with the 'act and content' psychology of the Austrian School" (Ogden 1911, p. 190). ${ }^{13}$ In his review of Ach, Külpe himself refers to the act-content distinction, claiming that "it is only by unifying the two standpoints [i.e., the standpoint of act psychology and that of content psychology, AD] that one will reach a complete overview of the mental facts" (Külpe 1907, p. 603). The most striking consequence of this claim lies in the fact that Külpe endorses a dualist view of the mind. ${ }^{14}$ On this view, the mental life is made up of two basic kinds of ingredients: sensory, imaginatory or intellectual contents on the one hand, and acts directed at those contents on the other. Acts are here conceived of as "subjective operations" (subjective Betätigungen) exerted on mental contents (Külpe 1912b, pp. 117-118).

\12 of Külpe's Lessons on Psychology offers another exposition of this dualist view, along with a new terminology. Cognitive experiences, Külpe writes, are best described as "attitudes" (Verbaltungsweisen), viz. ways of behaving toward something. Under attitude, Külpe precisely understands a complex state which is made up, minimally speaking, of the subjective apprehension of a content. The subjective apprehension correspond to what is called the mental 'act' and is typically expressed by a mental verb (e.g., 'believing'), while the content typically is captured by a that-clause or a nominal group (Külpe's attitudes do not necessary need to be thought of as propositional attitudes). Such attitudes may be simple, like when the subject merely notices something or acknowledges that something is the case. But they may be complex as well, as in ethical or theoretical behaviour (Külpe 1922, pp. 129-130). Moreover, the contents may be of various kinds. The notion of 'content,' broadly understood, encompasses sense impressions, mnemonic images and images (re)created by the imagination, thoughts (Gedanken) or intellectual contents (gedankliche Inbalte), as well as pain and pleasure (id.). Similarly, it is clear that subjective stances are of various kinds as well. For a given content $C$, the subject may perceive $C$, remember $C$, know $C$, notice $C$, meaning $C$, thinking of $C$ (in the narrow sense of the term), acknowledging or rejecting $C$, loving or hating $C$, etc. Accordinly, one's mental life is likely to be analyzed into a huge variety of cognitive and noncognitive attitudes, each of them being made up of a certain subjective stance toward a certain content.

To Külpe's mind, this view is clearly meant to unify the various terminological innovations brought up by the other Würzburgers. Using Stumpf's notion of 'function' as synonymous to the notion of 'mental act,' Külpe maintains that "standpoints, tasks, determining tendencies hold true only for functions, not for contents" (Külpe 1922, p. 133). Marbe's "situations of consciousness" also are identified with conscious attitudes (Ogden 1911, p. 185). But above all, Külpe insists that the act-content distinction should be attributed some prominence over the traditional division in thinking, feeling and wanting (Külpe 1922, p. 129; Messer 1928, p. 50). It offers a new standpoint for the description of mental facts in the broadest sense of the term.

This is not to say, of course, that the cognitive character of cognitive experiences only lies on the attitudinal side. The content matters, too. When I think of what I will do within the next days, or when I figure out the solution to some abstract problem, the contents of my thinking

'act' (see also Bühler 1908b, p. 1). They therefore distinguish between 'mental functions' and 'mental contents' in much the same sense as contemporary analytic philosophers distinguish between 'mental acts' and 'mental contents.' ${ }^{13} \mathrm{It}$ is common knowledge that the act-content distinction later on became familiar in both phenomenological and analytic traditions.

${ }^{14}$ No need to say, this dualist view has nothing to do with a dualist approach to the mind-body problem. 
acts do not seem to be reducible to sensory or imaginatory contents. And yet, they are "unequivocally determined", even though their intrinsic complexity makes it difficult for the subject to verbalise them (Ach 1905, p. 41 fn.; Külpe 1907, p. 603). To put it in contemporary terms, the content of a thought is neither general nor vague, it is "explicit" and "presents itself as a unit"; it does not need to be "unfolded" through verbalisation, be it silent ("inner speech") or not (Hurlburt \& Akhter 2008, pp. 1366-1367). This determined character of non-imagistic contents explains why Külpe, Bühler and other Würzburgers acknowledge the existence of intellectual contents at all (see Bühler 1908b, p.5). To be sure, the introduction of such intellectual contents is a significant contribution to the description of cognitive experiences. It is true that the change of attitude generates a change of content, too. When I switch from absentminded hearing-hearing-without-understanding - to hearing-cum-understanding, I come to experience an intellectual content in addition to the sensory content. More exactly put, I now take the sensory content to be the expression of an intellectual content.

Why not stiking with a merely contentual approach? As far as I can see, the main rationale for introducing the act-content distinction is that the act may vary independently from the content. First, Külpe argues, contents and acts me be combined in various ratios. There are passive behaviours in which we just receive sensory, imaginatory or intellectual contents, without actively handling them, as this seems to be the case in the secretary example: the sentences uttered by the secretary are heard without being understood. On the other hand, in the case of thinkingexperiences like those involved in problem-solving, the mind's intellectual activity seems to be much more important. Next, "the same sense impression may be perceived, acknowledged, noticed, intended, judged” (Külpe 1922, p. 132). When I fail to understand a sentence, what lacks is the relevant cognitive attitude towards the sensory, imaginatory or intellectual contents. And when I eventually come to grasp its meaning, a change in the sensory phenomena does not need to occur (see Bühler 1908b, p. 2). ${ }^{15}$ Stumpf even go so far as arguing that a change in the sensory content cannot occur, since otherwise any act of comparison would be made impossible: For me to compare a content $C_{1}$ with another content $C_{2}, C_{1}$ and $C_{2}$ must remain unchanged while I perceive them, notice their different features, etc. (Stumpf 1906, p. 22; Bühler 1908b, p. 2). So, when I undergo a realising-experience to the effect that I now grasp the meaning of a sentence, I don't have just access to the intellectual content, but I apprehend it in a determined way-for example, in understanding it and not in endorsing it or questionning it. And I don't just have acces to the sensory content, either, but I now take it to be the expression of an intellectual content. Each content, so to speak, goes hand in hand with a determined way of apprehending it, which is likely to vary independently from it. Therefore, in the case of the understanding-experience, the overall attitude may be said to involve a perceptual as well as a cognitive mode.

If the dualist view advocated by Külpe is on the right track, then, it is quite inappropriate to conceive of the subject's mental live as successions of presentations or ideas (sensations or feelings) ruled by laws of association. Adding intellectual contents won't do the trick, either. Again, the main rationale is the adequacy of our descriptions to empirical facts: "The supposition that

\footnotetext{
${ }^{15}$ Interestingly, Stumpf himself suggests that this acknowledgement of the independent variability of our mental functions paves the way for a serious treatment of thought processes or intellectual functions: "The conceptual thought, in all its operations-analytic, synthetic, etc.- turns out to be much more independent from the phenomena (images) than usually believed et taught for a long while in association psychology. Even what has been called inner speech is not, at every moment, an inescapable component of tought processes" (Stumpf 1906, p. 25). Stumpf refers to experimental investigations on thought processes made, among others, by Binet and Ach.
} 
our mental life is a scene for the kaleidoscopic changing of contents" is "incompatible with the facts" (Külpe 1922, p. 131). What lacks in this traditional picture is the fact that the subject commonly grasps, or fails to grasp, some thoughts and takes a stance toward them. In the friend and the train examples, I fail to recognise something for what it is: I fail to recognise the face I see as that of my friend, or the sound I hear as that of a train.

\section{The Phenomenality of Cognitive Attitudes}

I have dwelt so far on Külpe's first claim, according to which cognitive experiences like those mentioned in section 1 are best described in terms of cognitive attitudes. Yet, as suggested in the introduction, I believe Külpe's conception of cognitive experiences also centers around another major claim, namely, the claim that cognitive attitudes are phenomenally manifest to the subject or, in contemporary terms, have a phenomenology — a claim which sharply contrasts with the prominent view in mainstream analytic philosophy.

True, acts and contents are not experienced by the subject in exactly the same way. On the contrary, another major reason for distinguishing acts from contents, Külpe adds, lies in the fact that acts, unlike contents, cannot be observed while they are experienced:

I cannot observe my [act of] thinking during [my act of] thinking itself, whereas I can very well apprehend and analyse something red or bitter, a smell of camphor or an organ sound while they are given to me (Külpe 1907, p. 603; see also 1922, p. 132).

Külpe obviously takes it that observation implies attention. Since, before any act of reflection, our undivided attention is entirely focused on the content of our mental acts, it follows that mental acts can be observed only in restrospect, after their termination. ${ }^{16}$ This, Külpe writes, explains why they escape the attention of psychologists for such a long time, and why experimental psychology has been wrongly thought of as coextensive with content psychology.

That said, Külpe insists that acts are not mere add-ons to which we refer for explanatory purposes. Acts are not postulated; they are experienced. As he puts it:

The subject's activity [Betätigung] towards the contents is not a hypothesis, an assumption, but a fact of consciousness. I experience something else when I want to reach a goal and when I assess a thought or expect an event to occur (Külpe 1922, p. 133; my emphasis). ${ }^{17}$

Even though they are not amenable to observation while they are performed, mental acts are no less intransitively conscious, in the sense that the subject is conscious of them. What makes cognitive experiences 'experiences' is the fact that the cognitive attitude-and not only the intellectual content - is experienced by, or phenomenally manifest to, the subject. This somewhat illuminates Külpe's statement about the distinctive phenomenal character of cognitive experiences:

\footnotetext{
16 The argumentation is classical. Different versions of it may be found in Comte, Mill, and Brentano, among others. ${ }^{17}$ This view, again, is very close to that of Stumpf. In his review of Stumpf 1906, Bühler insists in turn that "the functions $[=$ acts, $\mathrm{AD}]$ are no less immediate objects of self-perception than phenomena (Erscheinungen) and, like the latters, they are part of the actuality of consciousness" (Bühler 1908b, p. 1).
} 
Non-intuitive knowledge — thinking and meaning — also is a 'phenomenon', and there is absolutely no need to reduce it to such [sensory or emotional] 'elements' to establish that it is so (Külpe 1907, p. 603).

Our phenomenal world is not exhausted by sensory or emotional contents. On the proposed interpretation, occurrent non-intuitive thinking is a phenomenon in the sense that it involves an overall attitude that is phenomenally manifest to the subject. ${ }^{18}$

As we see, Külpe's version of CCA rests upon the claim that we have "immediate consciousness of the activities themselves" (id., p. 134). He obviously conceives of this immediate consciousness as pre-reflective, since it has to be distinguished from self-observation or introspection. Now, plainly, this view is not without some difficulties. Külpe himself is not very explicit about the reason why we should accept the claim that attitudes are phenomenally conscious. Unlike Sartre, who endeavours to make his theory of pre-reflective self-awareness intuitively plausible on an introspective basis (see Sartre 1943/2000, p. 19), Külpe offers only poor support for this claim. Furthermore, one main challenge for supporters of CCA is to say more about the distinctive way mental attitudes are phenomenally manifest to the subject. Külpe's own indications, in this respect, are desperately vague and probably need to be supplemented by further critical considerations. Bühler made a very similar point in his review of Stumpf, suggesting that the phenomenality of cognitive attitudes was likely to be understood in different ways (Bühler 1908b, pp. 4-5). Is it a non-representational acquaintance with the occurrent attitude? Does it imply a minimal form of objectification and representation? Or is the occurrent cognitive attitude simply apprehended in restrospect as being similar to, or different from, past experiences? Külpe's theory, it seems, simply let those questions unanswered. ${ }^{19}$

\section{Conclusion}

On a classical interpretation, representatives of the Würzburg School have been unpersuasive in their attempts to establish 'thoughts' as distinctive ingredients of human mental life. The fact that Külpe's Lessons on psychology contains no chapter exclusively dedicated to thought is sometimes seen as a symptom of the failure of the thought-psychology research programme. ${ }^{20} \mathrm{I}$ believe this usual narrative is somewhat unfair. In light of the proposed reconstruction, it appears that Külpe and the Würzburgers anticipated a number of challenging ideas that emerged again in contemporary debates about cognitive phenomenology, like the idea that cognitive experiences are pervasive in human life, the (highly disputed) idea that perceiving-as involves a cognitive ingredient, or the idea that intellectual contents are experienced as unequivocally determined without being verbalised.

However, unlike most of classical analytic philosophers, Külpe favours an attitudinal

\footnotetext{
${ }^{18}$ I make no distinction here between being a phenomenon on the strong, technical sense of the term and being phenomenally manifest.

${ }^{19}$ Stumpf elaborated on a gradual theory of "inner perception" that accounts for different levels of apprehension (see Stumpf 1939, p. 340-1).

${ }^{20}$ See, e.g., Malone 2009, p. 323-7. There are several ways of accounting for this alleged failure. Among other things, Würzburgers were accused of confusing a priori or conceptual questions (questions about the grammar of the verb "to think") with empirical questions (questions that should be set in the lab), and to have wrongly assumed from the outset that there must exist some "isolable and describable ingredients of thinking" (Ryle 1953/2009, p. 309). This criticism, again, rests upon an ambiguity regarding the notion of "cognitive element" and is blind to Külpe's tentative revision of the architecture of the mind in terms of the act-content distinction.
} 
analysis of cognitive experiences. He therefore endorses a version of what I have called the theory of conscious cognitive attitudes. ${ }^{21}$ According to this theory, cognitive facts are best described in terms of distinctively cognitive attitudes towards sensory, imaginatory and/or intellectual contents. The argument from independent variability suggests that the notion of cognitive attitudes is inescapable when it comes to investigating the so-called 'imageless thoughts' (see also Ach 1905, p. 28). Even if the claim that cognitive attitudes are phenomenally manifest and contribute to the overall phenomenology of what I have called realising-experiences is not really argued for by Külpe, it is certainly worth further considerations.

To finish, let me add a word about the connection between Külpe's theory of cognitive attitudes and his main philosophical programme, namely, the epistemological foundation of 'realism' (see Külpe 1910, pp. 7-8; 1912a). Külpe himself suggests that his chief interest in the investigation of thought-processes is epistemological. It comes from his conviction that thought processes are the possibility condition of any reference to real entities and, consequently, of any empirical science inasmuch as it refers to real entities. This may be regarded as an additional claim: the act of thinking is "the instrument by means of which a positing and knowing of what is real becomes possible at all” (Külpe 1912c/1922, p. 319). While our sensory organs make us acquainted with appearances, thought gives us, so to speak, the undistorted thing, the thing in itself.' One way of capturing this idea is to say that thought is not perspectival in the same sense as perception. While I cannot possibly perceive the table without perceiving it form a certain perspective, I can think of the table without thinking of it from a certain perspective. Visually perceiving the table, e.g., involves being presented with a visual aspect of the table. Thinking of the table, on the contrary, does not literally involve being presented with an aspect of the table. As Külpe puts it: "One can immediately think of objects of the external world, like physical bodies, or of metaphysical objects, like Plato's Ideas or Leibniz's monads, without having to form some presentations of thereof' (Külpe 1922, p. 319). Whether or not this additional claim should be accepted is beyond the scope of this paper. ${ }^{22}$

\section{References}

Ach, N. 1905: Über die Willenstätigkeit und das Denken, Göttingen, Vandehoeck \& Ruprecht.

Baumgartner, E. \& Baumgartner, Wilhelm 1997: "Von Brentano zu Külpe. Die Deskriptive Psychologie Brentanos und die 'Würzburger Schule' der Denkpsychologie”, Brentano Studien, 7, pp. 31-52.

Bühler, K. 1907: “Tatsachen und Probleme zu einer Psychologie der Denkvorgänge: I. Über Gedanken”, Archiv für Psychologie, 9, pp. 297-365.

Bühler, K. 1908a: "Tatsachen und Probleme zu einer Psychologie der Denkvorgänge: II. Über Gedankenzusammenhänge”, Archiv für Psychologie, 12, pp. 1-23.

Bühler, K. 1908b: Review of C. Stumpf, "Erscheinungen und psychischen Funktionen”, Archiv für Psychologie, 11, pp. 1-5.

Caramelli, N. and Borghi, A. 1995: "La Psicologia a Würzburg. Il carattere teleonomico e selettivo del pensiero", Axiomathes, 3, pp. 349-374.

\footnotetext{
${ }^{21}$ In this respect, his contribution bears strong ressemblance to that of Stumpf or Husserl (for a reconstruction of Husserl's attitudinal approach, see Jorba 2016).

${ }^{22}$ I am grateful to two anonymous referees for many helpful comments and suggestions on a previous draft of this paper.
} 
Chudnoff, E. 2015: Cognitive Phenomenology, London, Routledge.

Dorsch, F. 2016: "The Phenomenology of Attitudes and the Salience of Rational Role and Determination”, Philosophical Explorations 19(2), pp. 114-137.

Gundlach, H. 1999: "Oswald Külpe und die Würzburger Schule", in W. Janke and W. Schneider (eds.), Hundert Jahre Institut für Psychologie und Würzburger Schule der Denkpsychologie, Göttingen: Hogrefe, pp. 107-124.

Hammer, S. 1994: Denkpsychologie - Kritischer Realismus. Eine wissenschaftshistorische Studie zum Werk Oswald Külpes, Frankfurt, Peter Lang.

Herrmann, T. 1999: "Otto Selz und die Würzburger Schule", in W. Janke and W. Schneider (eds.), Hundert Jahre Institut für Psychologie und Würzburger Schule der Denkpsychologie, Göttingen: Hogrefe, pp. 159-167.

Horgan, T. and Tienson, J. 2002: "The Intentionality of Phenomenology and the Phenomenology of Intentionality", in D. Chalmers (ed.), Philosophy of Mind. Classical and Contemporary Readings, Oxford, OUP, pp. 520-33.

Hurlburt, R. and Schwitzgebel, E. 2007: Describing Inner Experience? Proponent Meet Skeptic, Cambridge, The MIT Press.

Hurlburt, R. and Akhter, S. 2008: "Unsymbolized Thinking", Consciousness and Cognition, 17, pp. 1364-1374.

Jorba, M. 2016: “Attitudinal Cognitive Phenomenology and the Horizont of Possibilities”, in T. Breyer and C. Gutland (eds.), The Phenomenology of Thinking. Philosophical Investigations into the Character of Cognitive Experiences, London, Routledge, pp. 77-96.

Jorba, M. and Moran, D. 2016: "Conscious Thinking and Cognitive Phenomenology: Topics, Views and Future Developments", Philosophical Explorations, 19(2), pp. 95-113.

Kaiser-El-Safti, M. 1997: "Carl Stumpf und Oswald Külpe - ein Vergleich”, Brentano Studien, 7, pp. $53-80$.

Klausen, S. H. 2008: “The Phenomenology of Propositional Attitudes", Phenomenology and the Cognitive Sciences, 7(4), pp. 445-462.

Külpe, O. 1893: Grundriss der Psychologie auf experimenteller Grundlage dargestellt, Leipzig, Engelmann. Engl . transl. by E. B. Titchener, Outlines of Psychology Based upon the Results of Experimental Investigation, London, Swann Sonnenschein \& Co., 1895.

Külpe, O. 1902: “The Problem of Attention”, The Monist, 13(1), pp. 38-68.

Külpe, O. 1904: "Versuche über Abstraktion", in F. Schumann (ed.), Bericbt über den I. Kongreß für experimentelle Psychologie, Leipzig, Barth, pp. 56-68.

Külpe, O. 1907: Review of N. Ach, Über die Willenstätigkeit und das Denken, in Göttingische gelehrte Anreigen 169(1), p. 595-608.

Külpe, O. 1910: Erkenntnistheorie und Naturwissenschaft, Leipzig, Hirzel.

Külpe, O. 1912a: Die Realisierung. Ein Beitrag zur Grundlegung der Realwissenschaften, Bd. 1, Leipzig, Hirzel.

Külpe, O. 1912b: "Über die Bedeutung der modernen Denkpsychologie", in F. Schumann, (ed.), Bericht über den V. Kongress für experimentelle Psychologie, Leipzig, Barth, pp. 117-18.

Külpe, O. 1912c: "Über die moderne Psychologie des Denkens”, Internationale Monatsschrift für Wissenschaft, Kunst und Technik, 6, pp. 1069-1110. Reprinted in Külpe, O. 1922: Vorlesungen über Psychologie, $2^{\text {nd }}$ ed. by K. Bühler, Leipzig, Hirzel, pp. 297-331.

Külpe, O. 1922: Vorlesungen über Psychologie, $2^{\text {nd }}$ ed. by K. Bühler, Leipzig, Hirzel.

Kriegel, U. 2015: The V arieties of Consciousness, Oxford, OUP. 
Malone, J. C. 2009: Psychology. Pythagoras to Present, Cambridge, The MIT Press.

Marbe, K. 1901: Experimentell-psychologische Untersuchungen über das Urteil, Leipzig, Engelmann.

Messer, A. 1928: Empfindung und Denken, $3^{\text {rd }}$ ed., Leipzig, Quelle und Meyer.

Montague, M. 2016: The Given. Experience and its Content, Oxford, OUP.

Montague, M. 2017: "Cognitive Phenomenology", in D. M. Borchert (ed.), Philosophy: Mind, Palgrave Macmillan, pp. 297-326.

Ogden, R. M. 1911: "Imageless Thought: Résumé and Critique”, The Psychological Bulletin, 8(6), pp. 183-197.

Ogden, R. M. 1951: "Oswald Külpe and the Würzburg School”, The American Journal of Psychology, 64(1), pp. 4-19.

Pitt, D. 2004: “The Phenomenology of Cognition Or What Is It Like to Think That P?’, Philosophy and Phenomenological Research, 69(1), pp. 1-36.

Prinz, J. 2011: "The Sensory Basis of Cognitive Phenomenology", in T. Bayne and M. Montague (eds.), Cognitive Phenomenology, Oxford, OUP, pp. 174-196.

Rozestraten, R. J. A. 2004: “As tentativas dos cognitivistas pioneiros”, Estudos de Psicologia, 9(1), pp. 5-15.

Ryle, G. 1953: "Thinking”, Acta Psychologica, 9. Reprinted in Id., Collected papers, vol. 2: Collected Essays 1929-1968, London, Routledge, 2009, pp. 307-313.

Sartre, J.-P. 1943: L'Être et le Néant, Paris, Gallimard, reprinted 2000.

Schräder, H. 1924: Die Theorie des Denkens bei Külpe und bei Husserl, Münster (Dissertation).

Siegel, S. 2010: The Contents of Visual Experience, Oxford, OUP.

Siegel, S. and Byrne, A. 2016: "Rich or Thin?", in B. Nanay (ed.), Current Controversies in Philosophy of Perception, London, Routledge.

Siewert, C. 1998. The Significance of Consciousness, Princeton, Princeton University Press.

Siewert, C. 2007: “Who's Afraid of Phenomenological Disputes?”, The Southern Journal of Philosophy, 45, pp. 1-21.

Smithies, D. 2013: “The Nature of Cognitive Phenomenology”, Philosophy Compass, 8(8), pp. 744754.

Strawson, G. 1994: Mental Reality, Cambridge, The MIT Press, $2^{\text {nd }}$ ed. 2010.

Stumpf, C. 1906: Erscheinungen und psychische Funktionen, Abhandlungen der Königlich-Preußischen Akademie der Wissenschaften, Berlin, Verlag der Akademie.

Stumpf, C. 1939, Erkenntnislehre, Bd. I, Barth, Leipzig.

Titchener, E. B. 1909: Lectures on the Experimental Psychology of the Thought-Processes, New York, Macmillan.

Watt, H. J. 1904: Experimentelle Beiträge zu einer Theorie des Denkens, Leipzig, Engelmann. 